\title{
PENINGKATAN DAYA SAING PELAKU USAHA BERBAHAN BAKU UBI KAYU MELALUI TEKNOLOGI INFORMASI
}

\section{COMPETITIVE IMPROVEMENT OF CASSAVA BASED BUSINESS THROUGH INFORMATION TECHNOLOGY}

\author{
${ }^{1)}$ Aminudin*, 2)Eko Budi Cahyono \\ ${ }^{1,2}$ Informatika Fakultas Teknik \\ Universitas Muhammadiyah Malang \\ J1. Raya Tlogomas No. 246 Malang, Indonesia 65144 \\ *Email: aminudin2008@umm.ac.id, ekobudi@umm.ac.id
}

\begin{abstract}
ABSTRAK
Pengabdian kepada masyarakat ini bertujuan untuk mengembangkan produk unggulan daerah di Desa Tirtoyudo Kecamatan Tirtoyudo Kabupaten Malang. Pentingnya pengabdian ini dipicu oleh prospek bisnis berbahan baku ubi kayu baik karena dukungan Pemerintah maupun karena bahan pangan tersebut menjadi salah satu komoditas pertanian utama di Desa Tirtoyudo. Untuk mewujudkan hal tersebut maka dalam pengabdian ini dilakukan beberapa tahapan diantaranya adalah diskusi langsung dengan kelompok tani Desa Tirtoyudo, pelatihan pengolahan ubi kayu menjadi bahan makanan yang siap dikonsumsi, dan pembangunan aplikasi dengan tujuan menyederhanakan rantai distribusi dari produsen ke konsumen dengan memanfaatkan lingkungan Teknologi Informasi dan Komunikasi (TIK). Lingkungan TIK yang dibangun dapat dibuka device smartphone ataupun komputer. Berdasarkan hasil kegiatan pengabdian yang telah dilaksanakan, diketahui bahwa penggunaan instrumen teknologi informasi dalam kegiatan pemasaran mutlak dibutuhkan untuk memperlancar kegiatan tersebut.
\end{abstract}

Kata kunci: Ecosystem TIK; Rantai Distribusi; Ubi Kayu

\begin{abstract}
This community service aims to develop superior regional products in Tirtoyudo Village, Tirtoyudo District, Malang Regency. This service's importance is triggered by the prospect of a business made from cassava raw materials both because of the support of the Government and because this food is one of the leading agricultural commodities in Tirtoyudo Village. To make this happen, in this service, several stages are carried out, including direct discussions with the Tirtoyudo village farmer groups, training on the processing of cassava into ready-to-consume food ingredients, and application development to simplify the distribution chain from producers to consumers by utilizing the ICT environment. The ICT environment that is built can be opened by a smartphone or computer device. Based on the results of community service activities, it is known that the use of information technology instruments in marketing activities is necessary to facilitate these activities.
\end{abstract}

Keywords: TIK Ecosystem; Distribution Chain; Cassava

Submitted : 2 Januari 2020 Revision : 26 Agustus 2020 Accepted : 2 September 2020 


\section{PENDAHULUAN}

Wilayah Kabupaten Malang merupakan salah satu kabupaten terluas kedua setelah Kabupaten Banyuwangi dengan luas $3.534,86 \mathrm{~km}^{2}$ atau $353.486 \mathrm{ha}$, maka tak ayal dengan luas wilayah seperti itu, sektor pertanian merupakan salah satu komoditas utama warga Kabupaten Malang. Salah satu Kecamatan yang menjadi basis sentral pertanian adalah Kecamatan Tirtoyudo. Secara geografis Desa Tirtoyudo berupa daratan sedang dengan ketinggian 500 meter di atas permukaan laut dan luas $824,25 \mathrm{Ha}$, terbagi 4 (empat) dusun, yaitu dusun Sukodono, dusun Krajan, dusun Sukomulyo dan dusun Sidodadi (Astuti et al., 2020). Secara wilayah, Kecamatan Tirtoyudo berdasarkan pembagian Wilayah Pengembangan (WP) pada dokumen Rencana Pembangunan Jangka Menengah Daerah (RPJMD) Kabupaten Malang maka wilayah Tirtoyudo termasuk dalam WP Turen dan Dampit (meliputi Kecamatan Turen, Kecamatan Dampit, Kecamatan Tirtoyudo, dan Kecamatan Ampelgading) dengan pusat pelayanan sosial di Turen, dan pusat pelayanan ekonomi di Dampit. Kecamatan ini memiliki potensi pengembangan sub sektor pertanian (tanaman pangan dan perkebunan), peternakan, perikanan laut, industri, pariwisata, serta kehutanan. Sekitar $40 \%$ hasil pertanian berupa ubi kayu sehingga ubi kayu termasuk komoditas unggulan yang menjadi tumpuan pencaharian bagi sebagian besar penduduk.

Peningkatan kesejahteraan penduduk dilakukan melalui pembangunan bidang ekonomi yang berkelanjutan. Salah satu yang perlu dilakukan adalah perbaikan dalam nilai tambah dan tata niaga hasil pertanian. Oleh karenanya disepakati pendirian pabrik pengolahan tepung Mocaf skala kecil kapasitas 2 (dua) ton per hari sesuai dengan luas lahan panen dan produktivitas kelompok tani ubi kayu yang ada di Desa Tirtoyudo.
Pabrik Mocaf mulai berproduksi sejak bulan Oktober 2016. Pasca produksi dihadapkan pada beberapa permasalahan diantaranya keterbatasan akses informasi antara produsen dengan konsumen, sehingga harga bahan baku dan produk yang sudah jadi tidak terkontrol secara maksimal. Hal ini yang mengakibatkan proses produksi dan proses pemasaran mengalami kendala di beberapa jaringan yang terbentuk. Disamping itu juga, jaringan distribusi konvensional yang terbentuk memiliki rantai distribusi yang panjang menyebabkan proses produksi dan pemasaran terhambat. Alur rantai distribusi konvensional memiliki alur dari petani ke pengepul, lalu ke distributor (besar atau kecil), ke agen, dan baru ke konsumen. Dengan rantai yang panjang tersebut membutuhkan biaya yang mahal dan hasil akhirnya akan berdampak pada mahalnya produk yang dibeli oleh konsumen (Cahyono et al., 2016).

Salah satu tujuan kegiatan pengabdian pada masyarakat ini ialah menyederhanakan rantai distribusi dari produsen ke konsumen dengan meniadakan pengepul dan agen dengan memanfaatkan media ecosystem Information and Communication Technology (ICT). Dengan strategi seperti ini diharapkan mahalnya biaya distribusi dapat tereduksi sehingga barang yang dibeli oleh konsumen jadi lebih terjangkau. Untuk meminimalisir biaya produksi dan distribusi, maka dalam kegiatan pengabdian ini juga menggandeng beberapa pihak yang terkait untuk memaksimalkan kinerja dari proses produksi sampai proses pemasaran dengan memanfaatkan teknologi informasi (Mumtahana et al., 2017) (Jauhari, 2010). Aplikasi yang dibangun diharapkan dapat mengakomodir kebutuhan mulai dari kelompok tani (untuk menghasilkan bahan baku), distributor, dan konsumen. Hal ini dilakukan untuk menyederhanakan rantai distribusi dari rantai pemasok sampai konsumen dan diharapkan dengan adanya 
penyederhanaan distribusi tersebut biaya distribusi lebih murah dan pastinya harga produk yang dibeli oleh konsumen juga lebih terjangkau (Suhari, 2011).

Kebutuhan teknologi informasi di berbagai sektor merupakan salah satu tuntutan dalam proses bisnis dan kehidupan (Supriyanto, 2004). Dengan pemanfaatan teknologi informasi maka pelaku usaha dapat dipermudah kinerjanya terutama pelaku usaha berbahan baku ubi kayu. Teknologi informasi ini nantinya digunakan untuk mengintegrasikan dan menghubungkan seluruh mitra yang ada di dalam kegiatan pengabdian pada masyarakat ini. Kebutuhan data dari konsumen dalam hal ini diwakili oleh produsen di tingkat akhir yaitu permintaan kebutuhan dari konsumen akan terekam ke dalam sistem, sehingga data tersebut akan langsung diketahui oleh distributor serta diketahui oleh kelompok tani selaku penyedia bahan baku. Pada akhirnya dengan terbangun sistem seperti ini, maka jadwal permintaan dan penyediaan barang dapat diketahui, permintaan dan penawaran barang dapat diketahui oleh semua pihak yang berada di dalam jaringan distribusi, sehingga permainan harga dapat diminimalisir. Diharapkan dengan terbangun sistem semacam ini maka harga bahan baku di tingkat petani dapat stabil, jelas, serta harga produk di tingkat konsumen juga dapat dikontrol secara maksimal. Bahan baku naik di sisi penyedia bahan baku dengan barang yang sama tetapi memiliki harga yang lebih murah di sisi konsumen. yang tersedia untuk menanam ubi kayu sangat melimpah apalagi di daerah Kecamatan Tirtoyudo yang mayoritasnya petani yang menanam ubi kayu dikarenakan tanahnya memang mendukung untu budidaya ubi kayu. Berdasarkan data yang dihimpun desa, diketahui bahwa $40 \%$ petani di daerah tersebut menanam ubi kayu dan hampir setengah atau 50\% dari lahan pertanian di daerah tersebut tanahnya cocok untuk ditanami ubi kayu. Begitu pula, setelah menjadi bahan jadi, ubi kayu dapat diolah menjadi olahan bahan pabrik dan pendamping makanan pokok sampai menjadi bahan olahan makanan pokok (Elvia, 2016).

Upaya penyederhanaan rantai distribusi dari penyedia bahan baku sampai ke konsumen dilakukan dengan pemanfaatan teknologi informasi. Hal ini penting agar informasi harga yang tersedia antara penyedia bahan dan konsumen bersifat transparan. Dengan demikian maka harga bahan baku di tingkat petani stabil dan harga produk di tingkat konsumen dapat lebih terjangkau. Untuk mendukung tercapainya tujuan tersebut, pembuatan kegiatan aplikasi dilakukan sebagaimana diagram berikut :

\section{METODE}

\section{Analisa Masalah dan rancangan kegiatan}

Berdasarkan analisa yang sudah dipaparkan di atas bahwa peluang bisnis berbahan baku ubi memang sangat prospektif dan produktif dilihat dari berbagai segi. Dari segi bahan baku, lahan 


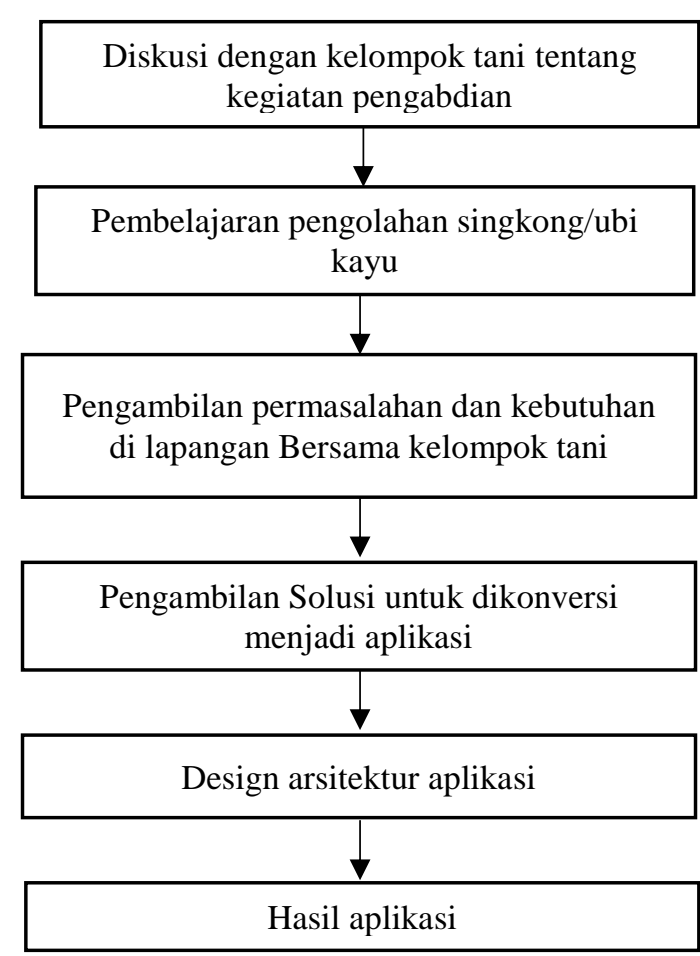

Gambar 1. Konfigurasi Teknologi

Berdasarkan Gambar 1 dapat dilihat bahwa untuk menghasilkan aplikasi yang sesuai dengan kebutuhan petani, distributor, sampai dengan produsen maka harus dilakukan tahap dari bawah yaitu dari sisi petani. Tim pengabdian harus mendiskusikan secara cermat dengan kelompok tani di desa Tirtoyudo tentang permasalahan yang terjadi seiring dengan pemasaran ubi kayu tersebut. Dari permasalahan tersebut nantinya dapat dibuat sebuah kebutuhan untuk dapat dikembangkan sebuah aplikasi. Terkait dengan pembelajaran juga, di dalam kegiatan ini juga mengadakan pelatihan pengolahan ubi kayu/singkong dijadikan olahan untuk dapat dikonsumsi. Pembelajaran tersebut langsung diisi oleh ketua kelompok tani dan pesertanya adalah warga sekitar desa Tirtoyudo.

\section{Diskusi dengan ketua Kelompok Tani}

Tahap ini dilakukan untuk merencanakan program pengabdian yang dilaksanakan, observasi terkait dengan potensi penyediaan bahan baku yang ada di desa Tirtoyudo, dan untuk menghubungi mitra yang terkait dengan pengabdian. Adapun mekanisme dalam tahap persiapan ini adalah sebagai berikut :

a. Berkoordinasi dengan ketua Kelompok Tani Ubi Kayu Desa Tirtoyudo yaitu Bapak Didik Sudarmoko terkait dengan potensi bahan baku dan permasalahan pemasaran ubi kayu. Dalam kesempatan ini juga membuat perencanaan dan jadwal sosialisasi kepada anggota kelompok tani di Desa Tirtoyudo

b. Membuat rancangan solusi terkait dengan permasalahan penjualan dan pemasaran ubi kayu selama ini.

\section{Pengambilan kebutuhan dan permasalahan di lapangan}

Pengambilan kebutuhan ini dilakukan untuk menjawab permasalahan yang terjadi di lapangan. Intinya adalah mempertemukan produsen, distributor, dan pembeli (konsumen) dengan didukung oleh lingkungan TIK. Dikarenakan kalau ketiga aktor tersebut dipertemukan dan saling percaya maka proses transaksi jual-beli akan berlangsung dengan aman dan efisien. Berdasarkan dari pengambilan kebutuhan di lapangan, diketahui bahwa harga sebuah produk akan mahal karena dipengaruhi oleh beberapa faktor diantaranya :

a. Konsumen tidak mengetahui harga dari produsen, jadi dalam hal ini semacam yang disebut dengan 'hidden value', sehingga harga barang dapat dimainkan oleh orang yang berkepentingan.

b. Lokasi barang yang dibeli oleh konsumen jaraknya jauh sehingga berdampak pada biaya transportasi yang ditanggung oleh konsumen.

c. Proses rantai distribusi dari produsen ke konsumen panjang sehingga memakan biaya transportasi dan produksi. 
d. Harga barang mengikuti atau ditentukan oleh harga pasar.

e. Tidak adanya hukum permintaan dan penawaran dari produsen dan konsumen atau intinya harga sudah paten ditentukan oleh produsen.

f. Konsumen tidak dapat memilih harga terendah dikarenakan harga sudah dipatok mengikuti harga pasar.

\section{Pengambilan Solusi Untuk dikonversi menjadi aplikasi}

Berdasarkan beberapa poin permasalahan yang dijelaskan di atas, dapat dicover oleh proses bisnis yang dijalankan oleh TIK. Maka dalam kegiatan pengabdian kepada masyarakat ini titik tekannya adalah pada proses bisnis yang berjalan berdasarkan dari penggunaan ekosistem TIK. Permasalahan tersebut dapat diselesaikan dengan menggunakan teknologi TIK yang dilengkapi dengan fitur sebagai berikut :

a. Konsumen dapat memilih barang yang dicari dengan harga terendah dan lokasi yang terdekat dengan produsen maupun distributor. Hal ini dapat memangkas harga produk yang akan dibeli oleh konsumen.

b. Konsumen dan distributor dapat melakukan penawaran harga dengan produsen di dalam lingkungan TIK.

c. Konsumen dapat mengetahui harga dari produsen, sehingga ketika konsumen akan membeli barang sudah mengetahui harga awal yang dipatok oleh produsen maupun distributor.

d. Dengan menggunakan TIK, dapat diketahui titik lokasi konsumen yang sering membutuhkan produk bahan ubi kayu, sehingga nanti distributor dapat diarahkan ke titik lokasi tersebut untuk memangkas biaya produksi.

e. Dengan menggunakan lingkungan TIK, maka dapat terdeteksi ketika ada konsumen membeli harga tinggi, maka nanti dapat dievaluasi bahwa apakah di dekat konsumen tersebut tidak ada distributor. Jika memang kalau tidak ada, maka distributor dapat ditarik ke titik lokasi tersebut.

f. Begitupula sebaliknya ketika distributor di dalam suatu titik lokasi tertentu sudah banyak, maka distributor tersebut dapat diarahkan ke titik lokasi distributor yang masih sedikit dengan mempertimbangkan banyaknya konsumen di daerah tersebut.

g. Dengan menggunakan TIK, hukum permintaan dan penawaran berlaku. Ketika barang yang diminta oleh konsumen banyak, maka harga akan semakin terjangkau.

h. Dengan menggunakan lingkungan TIK, maka proses timbal balik akan terjadi secara efisien. Baik produsen, distributor, dan konsumen akan saling diuntungkan dengan harga yang stabil di tingkat produsen dan terjangkau di tingkat konsumen.

Point-point tersebut yang ada di dalam lingkungan TIK sebagai acuan proses produksi yang diharapkan dapat membantu pihak produsen sebagai penyedia bahan baku untuk menjadikan harga yang stabil dan menjadikan produk yang dibeli oleh konsumen terjangkau. Dengan catatan apabila semua komponen aktor yang terlibat di dalam proses pembelian dan penjualan produk bahan ubi kayu menggunakan TIK.

\section{Pembuatan Design Arsitektur Aplikasi}

IPTEK yang diterapkan kepada mitra yang tergabung dalam usaha bersama masyarakat adalah teknologi informasi yang disebut dengan KaspeSea (http://telokaspe,com). KaspeSea merupakan sistem dan aplikasi mobile web (berjalan pada platform Android, iOS dan Windows Mobile 10) yang digunakan sebagai media komunikasi bisnis pelaku 
usaha berbahan baku ubi kayu dengan konsumen. Informasi tersedia seperti daya bahan baku, lokasi, daya jangkau, harga, reputasi pengguna akan membantu meningkatkan daya distribusi dan daya beli masyarakat terhadap produk berbahan baku ubi kayu. Desain rancangan IPTEK yang dibangun ditunjukkan pada Gambar 2.

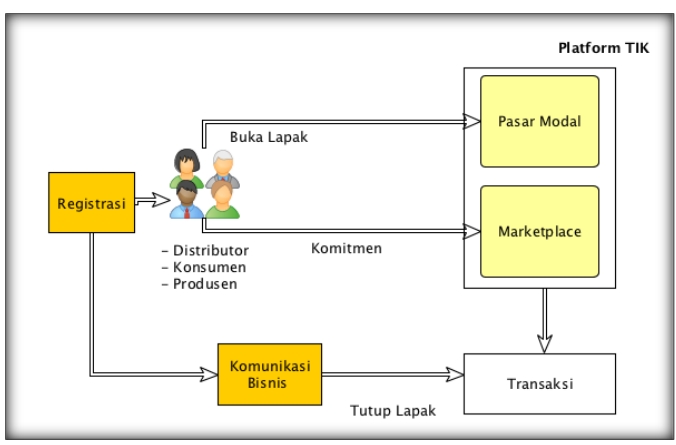

Gambar 2. Konfigurasi IPTEK yang dikembangkan

\section{HASIL DAN PEMBAHASAN}

Pelaksanaan pengabdian kepada masyarakat ini dilakukan melalui beberapa tahap diantaranya adalah :

\section{Diskusi dengan Kelompok Tani}

Diskusi ini dilaksanakan di desa Tirtoyudo bersama dengan ketua kelompok tani dan warga sekitar untuk mengetahui permasalahan yang terjadi di lapangan terkait dengan proses penjualan dan pemasaran hasil ubi kayu/singkong di desa Tirtoyudo.

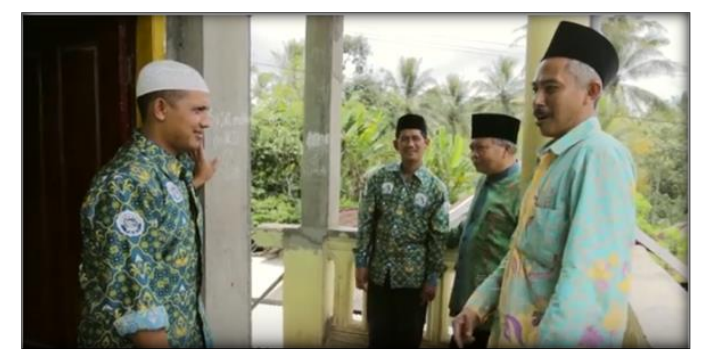

Gambar 3. Diskusi Bersama ketua kelompok tani Bapak Didik Sudarmoko bersama warga sekitar
Gambar 3 menunjukkan diskusi yang dilaksanakan bersama kelompok tani untuk membahas permasalahan yang terjadi terkait dengan pemasaran ubi kayu di daerah Malang Selatan. Disamping diskusi, juga dilakukan pengambilan data lahan yang dikelola oleh kelompok tani desa Tirtoyudo. Data ini digunakan untuk input data yang dilakukan pemrosesan oleh aplikasi. Berdasarkan laporan dari ketua kelompok tani, lahan petani yang sudah tergabung di dalam kelompok tani di desa Tirtoyudo diperkirakan 8 hektar dengan kapasitas produksi rata-rata 40 sampai dengan 50 ton per hektar. Data lahan yang dikelola oleh kelompok tani Desa Tirtoyudo ditunjukkan seperti pada Tabel 1 berikut.

Tabel 1. Lahan petani yang tergabung mitra pengabdian

\begin{tabular}{ccc}
\hline No & Pemilik & Luas Lahan $\mathbf{( m}^{\mathbf{2}} \mathbf{~}$ \\
\hline 1. & H. Tari & 7500 \\
2. & Munip & 5000 \\
3. & H.Suwandi & 30.000 \\
4. & Slamet & 2500 \\
5. & Porwanto & 2500 \\
6. & Riswadi & 2500 \\
7. & P mansur & 5000 \\
8. & Samari & 5000 \\
9. & H. Aswar & 3000 \\
10. & Halimah & 3000 \\
11. & P sa'rani & 5000 \\
12. & H Matasin & 3000 \\
13. & Khosim & 2500 \\
14. & Muslimin & 2500 \\
15. & p. suni & 5000 \\
16. & Holik & 5000 \\
17. & Hasan & 2500 \\
18. & Hosen & 5000 \\
19. & Suwanto & 5000 \\
20. & Yasmari & 2500 \\
21 & Yaseman & 2500 \\
\hline & Total & $\mathbf{7 6 5 3 0}$ \\
\hline
\end{tabular}


Pembelajaran Pengolahan Singkong menjadi olahan untuk dikonsumsi

Ketela pohon yang dihasilkan oleh kelompok tani desa Tirtoyudo adalah ketela pohon dengan jenis Singkong Gajah. Singkong Gajah merupakan komoditas atau jenis singkong yang ditemukan oleh Prof Ristono. Karakter Singkong Gajah ini sangat istimewa : gen batang yang cepat membelah dalam proses terbentuknya akar sehingga pohon Singkong Gajah ini bisa tumbuh dan sanggup menghasilkan jumlah atau umbi yang banyak. Gambar 4 merupakan singkong yang dihasilkan oleh kelompok tani desa Tirtoyudo.

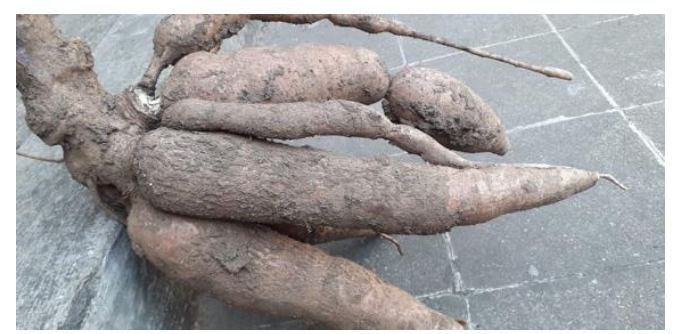

Gambar 4. Jenis singkong/ubi kayu yang dihasilkan oleh kelompok tani desa Tirtoyudo

Dengan jenis singkong yang begitu melimpah hal tersebut sangat prospek untuk dapat diolah menjadi olahan singkong yang berkualitas. Hal inilah, yang menginisiasi pelaksana kegiatan pengabdian untuk melakukan pembelajaran pengolahan singkong menjadi bahan yang siap untuk dikonsumsi. Gambar 5 menunjukan proses pembelajaran pengolahan ubi kayu menjadi bahan siap konsumsi.

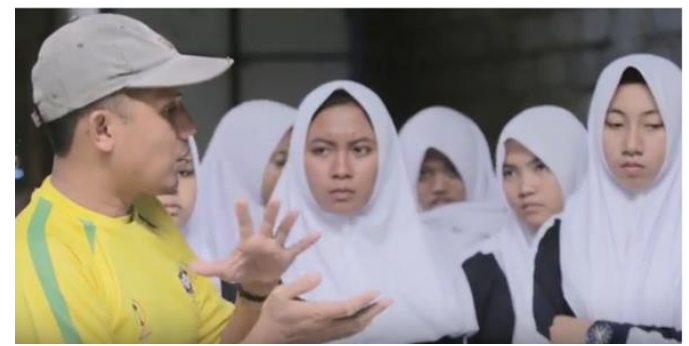

Gambar 5. Pembelajaran pengolahan ubi kayu/singkong menjadi bahan yang siap dikonsumsi

\section{Hasil Aplikasi}

Untuk mempermudah pemasaran hasil ubi kayu yang dihasilkan oleh petani ke konsumen, maka di dalam kegiatan pengabdian ini dibuatkan aplikasi dengan nama Kaspesea yang dapat diakses melalui alamat http://telokaspe.com. Tujuan dibuatkan aplikasi ini adalah untuk menjembatani penjual dan pembeli di dalam melakukan transaksi barang yang berhubungan dengan ubi kayu. KaspeSea merupakan sistem dan aplikasi mobile web (berjalan pada platform Android, iOS dan Windows Mobile 10) yang digunakan sebagai media komunikasi bisnis pelaku usaha berbahan baku ubi kayu dengan konsumen. Informasi tersedia seperti daya bahan baku, lokasi, daya jangkau, harga, reputasi pengguna akan membantu meningkatkan daya distribusi dan daya beli masyarakat terhadap produk berbahan baku ubi kayu. 


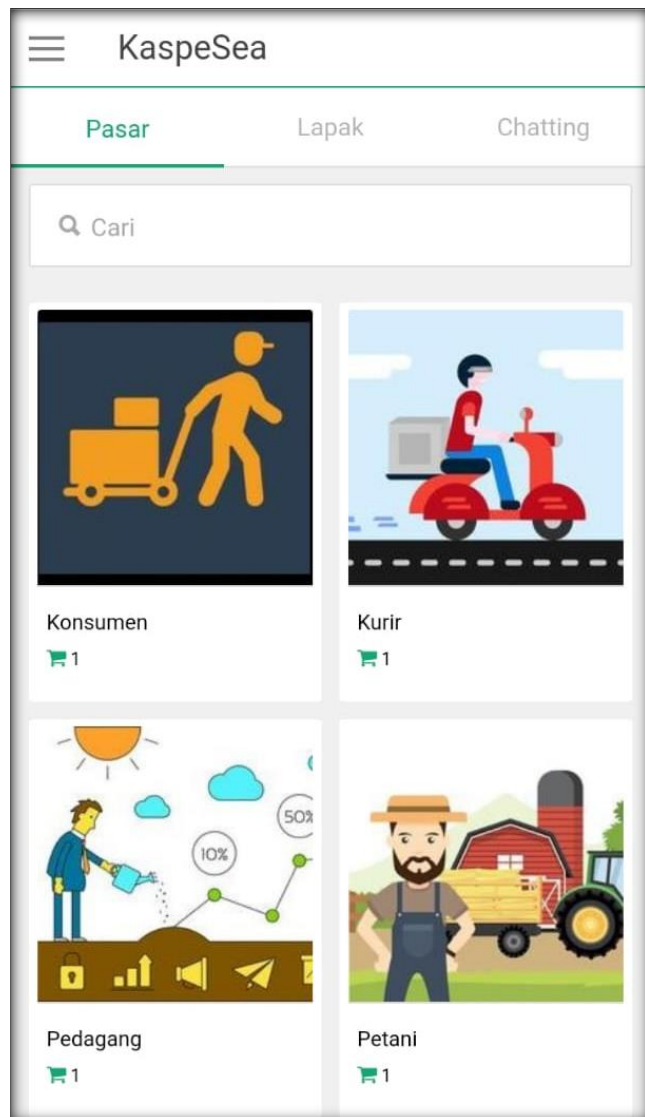

Gambar 6. Hasil aplikasi yang dibuka dengan menggunakan HP

Gambar 6 menunjukan bahwa aplikasi yang dibangun memiliki fitur sebagai berikut :

Konsumen : dalam hal ini merupakan industri rumah tangga yang membutuhkan bahan baku ubi kayu untuk diolah menjadi bahan yang siap untuk dikonsumsi.

Kurir : mewakili yang mengantarkan atau mendistribusikan barang.

Pedagang : fungsinya hampir sama seperti konsumen.

Kelompok tani : untuk mewakili kelompok tani yang menghasilkan ubi kayu, nantinya petani untuk menjual ubi kayu tersebut hanya menginformasikan harga, jenis singkong dsb.

\section{KESIMPULAN}

Berdasarkan hasil kegiatan pengabdian kepada masyarakat yang telah dilaksanakan dapat disimpulkan bahwa di dalam melakukan pemasaran barang atau jual beli dalam hal ini pemasaran berbahan baku ubi kayu instrumen teknologi informasi mutlak dibutuhkan di dalam memperlancar kegiatan tersebut. Dengan pemanfaatan teknokogi informasi, maka akan diperoleh kondisi adanya transparansi harga produk di tingkat pembeli dan penjual, sehingga memberikan keuntungan yang berimbang diantara keduanya.

\section{DAFTAR PUSTAKA}

Astuti, Z. D., Cahyono, E. B., \& Suharso, W. (2020). Game pembuatan beras Mocaf berbahan dasar tepung Mocaf "Beras Mocaf, Let's Do It." Jurnal Repositor. 2(4). https://doi.org/10.22219/repositor.v2i 4.77

Cahyono, E. B., Susanto, A., Juanda, A., \& Wahyudi, W. (2016). Pengembangan jaringan bisnis sosial berbasis komunitas pelaku usaha berbahan baku ubi kayu. Simposium Nasional RAPI XV - 2016 FT UMSFT UMS, $66,15-24$.

Elvia, R. (2016). Analisis nilai tambah ubi kayu sebagai bahan baku keripik singkong pada home industry Pak Ali di Desa Ujong Tanjung Kecamatan Mereubo Kabupaten Aceh Barat. (Skripsi tidak dipublikasikan). Fakultas Pertanian Universitas Teuku Umar Meulaboh, Aceh Barat.

Jauhari, J. (2010). Upaya Pengembangan Usaha Kecil dan Menengah (UMKM) dengan memanfaatkan E-Commerce. Jurnal Sistem Informasi. 2(1), 159168.

Mumtahana, H. A., Nita, S., \& Tito, A. W. (2017). Pemanfaatan Web E- 
Commerce untuk meningkatkan strategi pemasaran. Khazanah

Informatika: Jurnal Ilmu Komputer

Dan Informatika. 3(1).

https://doi.org/10.23917/khif.v3i1.33

09

Suhari, Y. (2011). Peran teknologi informasi dalam rantai pasokan. Jurnal Dinamika Informatika. 3(2). https://doi.org/10.35315/informatika. v3i2.1314

Supriyanto. (2004). Pemberdayaan Teknologi Informasi untuk Keunggulan Bisnis. Jurnal Ekonomi \& Pendidikan, 1(2), 99-112. https://doi.org/10.21831/jep.v1i2.666 